\title{
Dose-Fractionation Schedules for Radiotherapy of Bone Metastases
}

Dirk Rades

Department of Radiation Oncology, University of Lübeck, Germany

\section{Key Words}

Bone metastases - Radiotherapy - Bone pain .

Pathological fractures - Metastatic spinal cord compression

\section{Summary}

Background: Bone metastases are common in breast cancer patients. Radiotherapy is safe and effective. This review aimes to contribute to the definition of the appropriate radiation regimens for different endpoints. Material and Methods: Information was compiled by searching PubMed and MEDLINE databases including earlyrelease publications. When possible, primary sources were quoted. Full articles were obtained. References were checked for additional material when appropriate. Results: Randomized trials and meta-analyses demonstrated that single-fraction radiotherapy with $1 \times 8 \mathrm{~Gy}$ is as effective for pain relief as multi-fraction regimens such as $5 \times 4$ Gy or $10 \times 3 \mathrm{~Gy}$. Re-irradiation for recurrent pain is required more often after single-fraction radiotherapy. Re-irradiation with another single fraction is safe and effective. Multi-fraction long-course radiotherapy such as $10 \times 3 \mathrm{~Gy}$ leads to better re-calcification and better local control of metastatic spinal cord compression (MSCC). Because both re-calcification and MSCC recurrences occur only several months after radiotherapy, long-course radiotherapy is particularly appropriate for patients with a favorable survival prognosis. Conclusions: For uncomplicated painful bone metastases, single-fraction radiotherapy with $1 \times 8$ Gy may be considered the standard regimen. If re-calcification is a major goal, longer-course radiotherapy (i.e. $10 \times 3 \mathrm{~Gy}$ ) should be used. For MSCC, $10 \times 3 \mathrm{~Gy}$ is preferable for patients with a favorable survival prognosis.

\author{
Schlüsselwörter \\ Knochenmetastasen - Strahlentherapie . \\ Knochenschmerzen - Frakturen, pathologische . \\ Rückenmarkskompression, metastatisch bedingte
}

\section{Zusammenfassung}

Hintergrund: Knochenmetastasen kommen bei Brustkrebspatientinnen häufig vor. Die Strahlentherapie stellt eine sichere und wirksame Behandlung dar. Diese Übersichtsarbeit soll zur Definition geeigneter Strahlentherapie-Regime bei verschiedenen Endpunkten beitragen. Material und Methoden: Die Daten wurden durch eine Recherche der Datenbanken von PubMed und MEDLINE inklusive sogenannter „Early-Release Publications“ gewonnen. Wann immer möglich, wurden primäre Quellen zitiert. Vollpublikationen wurden berücksichtigt, und deren Literaturanhang wurde nach weiteren relevanten Quellen durchsucht. Ergebnisse: Randomisierte Studien und Metaanalysen haben gezeigt, dass eine Einzeit-Bestrahlung mit $1 \times$ $8 \mathrm{~Gy}$ ähnlich wirksam hinsichtlich des Endpunkts Schmerzerleichterung ist wie die fraktionierten Regime $5 \times 4$ Gy oder $10 \times 3 \mathrm{~Gy}$. Nach einer Einzeit-Bestrahlung ist häufiger eine Re-Bestrahlung erforderlich. Eine erneute EinzeitBestrahlung derselben Region ist sicher und wirksam. Eine fraktionierte Langzeit-Bestrahlung z.B. mit $10 \times 3 \mathrm{~Gy}$ führt zu einer besseren Remineralisierung und zu einer besseren lokalen Kontrolle einer metastatisch bedingten Rückenmarkskompression (MSCC). Da eine Remineralisierung und Rezidive einer MSCC zumeist erst Monate nach Bestrahlung auftreten, ist die Langzeit-Bestrahlung besonders für Patienten mit einer vergleichsweise guten Überlebensprognose geeignet. Schlussfolgerungen: Für unkomplizierte schmerzhafte Knochenmetastasen kann die Einzeit-Bestrahlung mit $1 \times 8 \mathrm{~Gy}$ als Standard-Regime angesehen werden. Wird eine Remineralisierung angestrebt, sollte eine Langzeit-Bestrahlung (z.B. $10 \times 3 \mathrm{~Gy}$ ) erfolgen. Bei der MSCC ist $10 \times 3$ Gy bei Patienten mit besserer Überlebensprognose zu bevorzugen.

\begin{tabular}{ll}
\hline KARGER & @ 2010 S. Karger GmbH, Freiburg \\
Fax +497614520714 & Accessible online at: \\
Information@Karger.de & www.karger.com/brc \\
www.karger.com &
\end{tabular}

Prof. Dr. med. Dirk Rades

Klinik für Strahlentherapie (Radioonkologie)

Universitätsklinikum Schleswig-Holstein, Campus Lübeck

Ratzeburger Allee 160, 23538 Lübeck, Germany

Tel. +49 451 500-6661, Fax -3324

rades.dirk@gmx.net 


\section{Introduction}

On autopsy, bone metastases are detected in up to $70 \%$ of breast cancer patients [1]. If (impending) pathological fractures or spinal cord compression occur, the metastases are defined as 'complicated'. Without such complications, the metastases are defined as 'uncomplicated'. Bone metastases are the most common cause of cancer-related pain [2]. With radiotherapy alone, significant pain relief can be achieved in up to $90 \%$ of patients, and complete freedom from pain can be expected in up to $50 \%$ of patients (tables 1-3) [3-18].
In addition to pain relief, the need for re-irradiation for recurrent pain and pathological fractures following radiotherapy are important endpoints for radiotherapy of painful bone metastases. The presence of bone metastases generally is a palliative situation. Patients with a poor survival prognosis may benefit from a radiation regimen with a short overall treatment time in order to avoid that these patients will have to spend much of their limited life span with treatment. However, such a short course of radiotherapy can only be recommended if it is as effective as longer radiotherapy programs. The major goal of this review was to contribute to the definition of the appropriate radiation regimen for different endpoints such as pain relief, pathological fractures, re-calcification, and metastatic spinal cord compression (MSCC).

Table 1. Randomized trials that compared single-fraction to multi-fraction short-course radiotherapy

\begin{tabular}{|c|c|c|c|c|}
\hline Trial & Overall pain response & Complete pain relief & Re-irradiation rate & Pathological fracture rate \\
\hline $\begin{array}{l}\text { Cole } 1989(\mathrm{n}=29)[17] \\
1 \times 8 \text { Gy } \\
6 \times 4 \text { Gy } \\
\text { Breast cancer patients: not stated }\end{array}$ & $\begin{array}{l}88 \% \\
85 \% \\
(p>0.05)\end{array}$ & $\begin{array}{l}\text { not stated } \\
\text { not stated }\end{array}$ & $\begin{array}{l}25 \% \\
0 \% \\
(\mathrm{p}<0.05)\end{array}$ & $\begin{array}{l}\text { not stated } \\
\text { not stated }\end{array}$ \\
\hline $\begin{array}{l}\text { Gaze et al., } 1997(\mathrm{n}=265)[5] \\
1 \times 10 \mathrm{~Gy} \\
5 \times 4.5 \mathrm{~Gy} \\
\text { Breast cancer patients: } \mathrm{n}=117(44 \%)\end{array}$ & $\begin{array}{l}84 \% \\
89 \%(p>0.05)\end{array}$ & $\begin{array}{l}39 \% \\
42 \%(p>0.05)\end{array}$ & $\begin{array}{l}\text { not stated } \\
\text { not stated }\end{array}$ & $\begin{array}{l}\text { not stated } \\
\text { not stated }\end{array}$ \\
\hline $\begin{array}{l}\text { Nielsen et al., } 1998(\mathrm{n}=241)[8] \\
\quad 1 \times 8 \text { Gy } \\
5 \times 4 \text { Gy } \\
\text { Breast cancer patients: } \mathrm{n}=94(39 \%)\end{array}$ & $\begin{array}{l}62 \% \\
71 \% \\
(\mathrm{p}>0.05)\end{array}$ & $\begin{array}{l}\text { not stated } \\
\text { not stated }\end{array}$ & $\begin{array}{l}21 \% \\
12 \% \\
(\mathrm{p}>0.05)\end{array}$ & $\begin{array}{l}5 \% \\
5 \% \\
(p>0.05)\end{array}$ \\
\hline $\begin{array}{l}\text { BPTWP } 1999(\mathrm{n}=761)[3] \\
1 \times 8 \text { Gy } \\
5 \times 4 \mathrm{~Gy}^{\mathrm{a}} \\
\text { Breast cancer patients: } \mathrm{n}=273(36 \%)\end{array}$ & $\begin{array}{l}72 \% \\
68 \% \\
(p>0.05)\end{array}$ & $\begin{array}{l}52 \% \\
51 \% \\
(p>0.05)\end{array}$ & $\begin{array}{l}23 \% \\
10 \% \\
(p<0.001)\end{array}$ & $\begin{array}{l}2 \% \\
<1 \% \\
(p=0.2)\end{array}$ \\
\hline $\begin{array}{l}\text { Steenland et al., } 1999(\mathrm{n}=1171)[12] \\
\quad 1 \times 8 \text { Gy } \\
6 \times 4 \text { Gy } \\
\text { Breast cancer patients: } \mathrm{n}=451(39 \%)\end{array}$ & $\begin{array}{l}72 \% \\
69 \% \\
(p=0.24)\end{array}$ & $\begin{array}{l}37 \% \\
33 \% \\
(p>0.05)\end{array}$ & $\begin{array}{l}25 \% \\
7 \% \\
(\mathrm{p}<0.001)\end{array}$ & $\begin{array}{l}4 \% \\
2 \% \\
(p<0.05)\end{array}$ \\
\hline $\begin{array}{l}\text { Roos et al., } 2005(\mathrm{n}=272)[11] \\
1 \times 8 \text { Gy } \\
5 \times 4 \text { Gy } \\
\text { Breast cancer patients: } \mathrm{n}=23(8 \%)\end{array}$ & $\begin{array}{l}53 \% \\
61 \% \\
(\mathrm{p}=0.18)\end{array}$ & $\begin{array}{l}26 \% \\
27 \% \\
(p=0.89)\end{array}$ & $\begin{array}{l}29 \% \\
24 \% \\
(\mathrm{p}=0.41)\end{array}$ & $\begin{array}{l}4 \% \\
4 \% \\
(p>0.05)\end{array}$ \\
\hline
\end{tabular}

Table 2. Randomized trials that compared single-fraction to long-course radiotherapy

\begin{tabular}{|c|c|c|c|c|}
\hline Trial & Overall pain response & Complete pain relief & Re-irradiation rate & Pathological fracture rate \\
\hline $\begin{array}{l}\text { Price et al., } 1986(\mathrm{n}=288)[16] \\
\quad 1 \times 8 \text { Gy } \\
10 \times 3 \text { Gy } \\
\text { Breast cancer patients: } \mathrm{n}=107(37 \%)\end{array}$ & $\begin{array}{l}21 \% \\
23 \%\end{array}$ & $\begin{array}{l}9 \% \\
9 \%\end{array}$ & $\begin{array}{r}11 \% \\
3 \%\end{array}$ & $\begin{array}{l}\text { not stated } \\
\text { not stated }\end{array}$ \\
\hline $\begin{array}{l}\text { Koswig and Budach } 1999(\mathrm{n}=107)[7] \\
\quad 1 \times 8 \mathrm{~Gy} \\
10 \times 3 \mathrm{~Gy} \\
\text { Breast cancer patients: } \mathrm{n}=23(8 \%)\end{array}$ & $\begin{array}{l}79 \% \\
82 \% \\
(p>0.05)\end{array}$ & $\begin{array}{l}31 \% \\
33 \% \\
(p>0.05)\end{array}$ & $\begin{array}{l}\text { not stated } \\
\text { not stated }\end{array}$ & $\begin{array}{l}\text { not stated } \\
\text { not stated }\end{array}$ \\
\hline $\begin{array}{l}\text { Hartsell et al., } 2005(\mathrm{n}=888)[6] \\
\quad 1 \times 8 \text { Gy } \\
10 \times 3 \text { Gy } \\
\text { Breast cancer patients: } \mathrm{n}=?(\sim 50 \%)\end{array}$ & $\begin{array}{l}65 \% \\
66 \% \\
(p=0.6)\end{array}$ & $\begin{array}{l}15 \% \\
18 \% \\
(p>0.05)\end{array}$ & $\begin{array}{l}18 \% \\
9 \% \\
(\mathrm{p}<0.001)\end{array}$ & $\begin{array}{l}5 \% \\
4 \% \\
(p>0.05)\end{array}$ \\
\hline $\begin{array}{l}\text { Foro Arnalot et al., } 2008(\mathrm{n}=160) \\
\quad 14] \\
10 \times 3 \text { Gy } \\
\text { Breast cancer patients: } \mathrm{n}=40(25 \%)\end{array}$ & $\begin{array}{l}75 \% \\
86 \% \\
(p>0.05) \\
\end{array}$ & $\begin{array}{l}15 \% \\
13 \% \\
(p>0.05) \\
\end{array}$ & $\begin{array}{l}28 \% \\
2 \% \\
(\mathrm{p}=0.001)\end{array}$ & $\begin{array}{l}\text { not stated } \\
\text { not stated }\end{array}$ \\
\hline
\end{tabular}


Table 3. Randomized trials that compared multi-fraction short-course to long-course radiotherapy

\begin{tabular}{|c|c|c|c|c|}
\hline Trial & Overall pain response & Complete pain relief & $\mathrm{Re}$-irradiation rate & Pathological fracture rate \\
\hline \multicolumn{5}{|l|}{ Tong et al., $1982(n=146)[13]$} \\
\hline [single metastasis] & $82 \%$ & $53 \%$ & not stated & $4 \%$ \\
\hline $5 \times 4$ Gy & $85 \%$ & $61 \%$ & not stated & $18 \%$ \\
\hline $15 \times 2.7 \mathrm{~Gy}$ & $(\mathrm{p}=0.82)$ & $(\mathrm{p}=0.42)$ & & $(\mathrm{p}=0.02)$ \\
\hline \multicolumn{5}{|l|}{ Breast cancer patients: not stated } \\
\hline \multicolumn{5}{|l|}{ Tong et al., $1982(n=613)[13]$} \\
\hline [multiple metastases] & $85 \%$ & $49 \%$ & not stated & $5 \%$ \\
\hline $5 \times 3 \mathrm{~Gy}$ & $83 \%$ & $56 \%$ & not stated & $7 \%$ \\
\hline $5 \times 4 \mathrm{~Gy}$ & $78 \%$ & $49 \%$ & not stated & $9 \%$ \\
\hline $5 \times 5 \mathrm{~Gy}$ & $87 \%$ & $57 \%$ & not stated & $8 \%$ \\
\hline $10 \times 3 \mathrm{~Gy}$ & $(\mathrm{p}=0.16)$ & $(\mathrm{p}=0.26)$ & & $(\mathrm{p}>0.05)$ \\
\hline \multicolumn{5}{|l|}{ Breast cancer patients: not stated } \\
\hline \multicolumn{5}{|l|}{ Okawa et al., $1988(\mathrm{n}=80)[15]$} \\
\hline $5 \times 4.5$ Gy & $75 \%$ & $40 \%$ & not stated & not stated \\
\hline $10 \times 2 \mathrm{~Gy}$ & $78 \%$ & $37 \%$ & not stated & not stated \\
\hline $15 \times 2 \mathrm{~Gy}$ & $76 \%$ & $41 \%$ & not stated & not stated \\
\hline Breast cancer patients: $\mathrm{n}=17(21 \%)$ & $(\mathrm{p}>0.05)$ & $(\mathrm{p}>0.05)$ & & \\
\hline \multicolumn{5}{|l|}{ Rasmusson et al., $1995(\mathrm{n}=217)[10]$} \\
\hline $3 \times 5$ Gy & $69 \%$ & not stated & not stated & not stated \\
\hline $10 \times 3 \mathrm{~Gy}$ & $66 \%$ & not stated & not stated & not stated \\
\hline Breast cancer patients: $\mathrm{n}=217(100 \%)$ & $(\mathrm{p}>0.05)$ & & & \\
\hline \multicolumn{5}{|c|}{ Niewald et al., $1996(n=100)[9]$} \\
\hline $5 \times 4$ Gy & $77 \%$ & $33 \%$ & $2 \%$ & $8 \%$ \\
\hline $15 \times 2 \mathrm{~Gy}$ & $86 \%$ & $31 \%$ & $2 \%$ & $12 \%$ \\
\hline Breast cancer patients: $n=43(43 \%)$ & $(\mathrm{p}>0.05)$ & $(\mathrm{p}>0.05)$ & $(\mathrm{p}>0.05)$ & $(\mathrm{p}>0.05)$ \\
\hline
\end{tabular}

\section{Material and Methods}

\section{Review Criteria}

The information for this review was compiled by searching the PubMed and MEDLINE databases. Electronic early-release publications were also included. The search terms used included 'bone metastases', 'bone metastasis', 'metastatic spinal cord compression', 'malignant spinal cord compression', 'metastatic epidural spinal cord compression', 'malignant epidural spinal cord compression', 'pathological fracture', and 'skeletal related event'. When possible, primary sources were quoted. Full articles were obtained and references were checked for additional material when appropriate.

\section{Pain Relief}

Single-fraction radiotherapy with $8 \mathrm{~Gy}$ was not inferior to multi-fraction regimens with respect to pain relief. These results have been confirmed in 3 meta-analyses. The mostimportant studies are summarized in tables $1-3$. Wu et al. [19] compared single-fraction radiotherapy with $1 \times 8$ Gy to multifraction regimens ranging from $5 \times 4$ Gy to $10 \times 3$ Gy in 3260 patients from 8 trials. In the per-protocol analysis, $39 \%$ of patients after $1 \times 8 \mathrm{~Gy}$ and $50 \%$ of patients after multi-fraction radiotherapy achieved complete pain relief (relative risk (RR) 0.98; 95\% confidence interval (CI) 0.89-1.07; p = 0.6). The overall response rates (intention-to-treat analysis) were 73 and $73 \%$, respectively (RR 1.00; 95\% CI 0.95-1.04; $\mathrm{p}=0.9$ ). Similar results have been demonstrated in the metaanalysis of Sze et al. [20], who included 3621 patients from 12 trials. The complete response rates were $34 \%$ after singleand $32 \%$ after multi-fraction radiotherapy (odds ratio (OR) 1.10; 95\% CI 0.94-1.30, p > 0.05). Overall response rates were
60 and 59\%, respectively (OR 1.03; 95\% CI 0.90-1.19; $\mathrm{p}>0.05)$. The meta-analysis of Chow et al. [21] included 5000 patients from 16 trials. The overall response rates (intentionto-treat analysis) were $58 \%$ after single- (mostly $1 \times 8$ Gy) and $59 \%$ after multi-fraction radiotherapy, mostly with $5 \times 4$ Gy or $10 \times 3$ Gy (OR 0.99; 95\% CI 0.95-1.03; p = 0.60). Complete pain relief was achieved in 23 and $24 \%(558 / 2351)$ of patients, respectively (OR 0.97 ; $95 \%$ CI $0.88-1.06$; $\mathrm{p}=0.51$.

\section{Recurrent Bone Pain}

A comparison of single- and multi-fraction radiotherapy for re-irradiation of recurrent bone pain in the previously irradiated region was performed in 6 trials (tables 1 and 2) [3, $4,6,8,11,12]$. In 4 trials, the re-irradiation rate was significantly higher after single- than after multi-fraction radiotherapy. In the meta-analysis of $\mathrm{Wu}$ et al. [19], pooled data were not presented for this endpoint. In the meta-analysis of Sze et al. [20], re-irradiation rates were $22 \%$ after single- and $7 \%$ after multi-fraction radiotherapy (OR 3.44; 95\% CI 2.67-4.43; $\mathrm{p}<0.05)$. In the meta-analysis of Chow et al. [21], re-irradiation rates were $20 \%$ after single- and $8 \%$ after multi-fraction radiotherapy (OR 2.50; 95\% CI 1.76-3.56; p < 0.0001). Whether the need for re-irradiation is really greater with a single-fraction regimen is still unclear. Re-irradiation after single-fraction radiotherapy is safe and effective [22, 23]. Acute toxicity does not exceed grade 2 . The response rates after re-irradiation are similar (74-87\%) to those after primary radiotherapy. If re-irradiation is required after primary long-course radiotherapy with total doses of $\geq 30$ Gy, re-irra- 
diation should be preferably delivered using high-precision techniques to better spare healthy tissues and reduce potential late toxicity. High-precision radiotherapy techniques include stereotactic body radiation therapy (SBRT), radiosurgery, and intensity-modulated radiotherapy (IMRT).

\section{Pathological Fractures after Radiotherapy}

4 of the 5 trials that investigated the pathological fracture rate in the irradiated region following radiotherapy did not demonstrate a significant difference between single- and multifraction radiotherapy (tables 1 and 2) [3, 6, 8, 11]. In the 5th study, more pathological fractures occurred after single-fraction radiotherapy with $1 \times 8$ Gy than after $6 \times 4$ Gy [12]. In the meta-analysis of $\mathrm{Wu}$ et al. [19], pathological fracture rates were not stated. In the meta-analysis of Sze et al. [20], pathological fracture rates were $3.0 \%$ after single- and $1.6 \%$ after multi-fraction radiotherapy, respectively (OR 1.82; 95\% CI $1.06-3.11 ; \mathrm{p}<0.05)$. In contrast, the more recent and larger meta-analysis of Chow et al. [21] did not demonstrate a significant difference. Pathological fracture rates were 3.2\% after single- and $2.8 \%$ after multi-fraction radiotherapy (OR $1.10 ; 95 \%$ CI $0.61-1.99 ; p=0.75)$. It remains unclear whether single-fraction radiotherapy is associated with a higher rate of pathological fractures than multi-fraction regimens. Regarding the assessment of pathological fractures following radiotherapy, it sometimes may be difficult to distinguish between fractures due to progression/recurrence of osteolytic bone metastases and radiation-induced fractures. However, the biologically effective radiation doses for the treatment of bone metastases are generally far below the tolerance dose of $55 \mathrm{~Gy}$ for bone damage.

\section{Toxicity of Radiotherapy}

The most common acute side effects are skin reactions. Gastrointestinal toxicity such as nausea/vomiting and diarrhea may occur if the irradiated bone metastases are close to stomach or bowels. There was a trend towards a higher acute toxicity rate with multi-fraction radiotherapy. Foro Arnalot et al. [4] reported 5\% grade 2-4 toxicity with $10 \times 3$ Gy versus $2 \%$ with $1 \times 8 \mathrm{~Gy}$. In another study, acute toxicity rates were $26 \%$ in the $5 \times 4.5$ Gy group and $22 \%$ in the $1 \times 10$ Gy group [6]. In the Radiation Therapy Oncology Group (RTOG) 97-02 trial, the acute toxicity rate was significantly higher with $10 \times 3$ Gy than with $1 \times 8$ Gy $(17 \%$ versus $10 \%, p=0.002)$ [6]. An intermittent aggravation of bone pain ('pain flare') may occur during radiotherapy. Pain flare rates range from 14 to $44 \%$ and can be reduced to $3 \%$ by prophylactic administration of $8 \mathrm{mg}$ dexamethasone [24-26].

\section{Re-Calcification}

In case of an (impending) pathological fracture, surgical stabilization should be performed. Postoperative long-course radiotherapy is required to avoid slackening or dislocation of the osteosynthetic material. Re-calcification of the osteolytic bone, which is best after long-course radiotherapy, can only be expected several months after radiotherapy and is therefore particularly important for patients with a relatively favorable survival prognosis [7]. The survival prognosis of patients with bone metastases can be estimated with the help of a specific scoring system reported by Van der Linden et al. [27]. However, this scoring system was developed in patients with metastases of the vertebral column, and may therefore not be generalized to patients with bone metastases at other locations.

\section{Metastatic Spinal Cord Compression}

Radiotherapy alone is effective in the treatment of MSCC in breast cancer patients. In a prospective study of 56 patients, back pain disappeared or lessened in $89 \%$ of patients [28]. 4 of 6 patients with urinary dysfunction responded to radiation therapy. Of 35 non-ambulatory patients, 21 patients regained the ability to walk. All 21 patients without motor deficits before treatment maintained good motor performance after radiation therapy. According to a retrospective study of 1304 MSCC patients, single-fraction radiotherapy, multi-fraction short-course radiotherapy, and long-course radiotherapy provided similar functional outcomes [29]. Overall response (improvement or no further progression) was about $85 \%$. Similar results were observed for 335 breast cancer patients [30]. $91 \%$ of these patients responded to single fraction/shortcourse radiotherapy with $1 \times 8$ Gy or $5 \times 4$ Gy, and $88 \%$ of patients responded to long-course radiotherapy with $10 \times 3 \mathrm{~Gy}$, $15 \times 2.5 \mathrm{~Gy}$, or $20 \times 2 \mathrm{~Gy}(\mathrm{p}=0.31)$. Recurrences of MSCC in the irradiated spinal region (in-field recurrences) are more common after single-fraction and short-course multi-fraction radiotherapy than after long-course radiotherapy. In a retrospective series of 1852 patients, the local control rates at 2 years were 74 and $90 \%$, respectively $(\mathrm{p}<0.001)$ [31]. Similar results were described for the subset of breast cancer patients [31]. The local control rates at 2 years were 80 and $90 \%$, respectively $(\mathrm{p}=0.008)$. A recent prospective study including various primary tumors also demonstrated long-course radiotherapy to be associated with fewer in-field recurrences [32]. Because patients with a favorable survival prognosis may live long enough to develop a recurrence, these patients should receive long-course radiotherapy. This applies in particular to patients with MSCC from breast cancer, for whom a median survival of 20 months was reported [30]. Survival of patients with MSCC can be estimated with a new scoring system [33]. Patients with a favorable survival prognosis may be consid- 
ered candidates for decompressive surgery preceding radiotherapy or for high-precision radiotherapy. Selected patients treated with decompressive surgery followed by long-course radiotherapy had a better post-treatment ambulatory status ( $84 \%$ versus $57 \%, p<0.001)$ than patients treated with radiotherapy alone in a small randomized trial of 101 patients [34]. High-precision radiotherapy techniques may be considered to reduce the risk of potential late toxicity.

\section{Radionuclide Therapy}

Pain relief from radionucleotides is best in osteoblastic lesions, and likely arises from inhibition of pain mediators from normal bone cells, not from a direct effect on the tumor. Strontium- 89 and samarium-153 are effective for bone metastases from solid tumors [35-37]. Up to $80 \%$ of patients with osteoblastic bone metastases from breast cancer may experience pain relief following strontium-89 administration [35]. Duration of clinical response usually lasts for several months. However, platelet and leukocyte counts usually fall by 25 $40 \%$. Samarium is less myelosuppressive than strontium but similarly effective. Because radionuclide therapy is myelosuppressive, chemotherapy can only be safely administered about 6 weeks later.

\section{External-Beam Radiotherapy for Generalized Bone Metastases}

External-beam radiotherapy for pain relief may also be administered for carefully selected patients with generalized bone metastases, in particular if they are not candidates for radionuclide therapy. In some countries, hemibody irradiation (HBI) is used [38-40]. HBI is generally administered either as upper HBI (above the umbilicus) or lower HBI (below the umbilicus). In many cases there is overlap between upper and lower HBI as it may be required to include the thoracic-lumbar vertebral column and the pelvic bone in one field. So, instead of HBI, one may use large-field irradiation. The maximum field size achieved with a modern linear accelerator is $40 \mathrm{~cm} 40 \mathrm{~cm}$ (source-skin distance $100 \mathrm{~cm}$ ). Lungs are the critical dose-limiting organs. As the pneumonitis rate increases beyond $1 \times 6 \mathrm{~Gy}$, the recommended dose for upper HBI or large-field irradiation above the diaphragm is $1 \times 6$ Gy. Below the diaphragm, $1 \times 8$ Gy is possible. Splitting the dose into 2 fractions did not show any benefit [39]. Large- field irradiation is associated with increased acute toxicity compared to local irradiation. Prophylactic administration of antiemetic drugs and dexamethasone is recommended. Bone marrow depression is common and may last up to 6 weeks like after radionuclide therapy. Significant pain relief was observed in $70 \%$ of patients after HBI or large-field irradiation $[38,40]$.

\section{Bisphosphonates}

Particularly in patients with a favorable survival prognosis, radiotherapy should be supplemented by bisphosphonates to further enhance re-calcification and to reduce the risk of an in-field recurrence of MSCC following radiotherapy. Studies demonstrated the efficacy of bisphosphonates in reducing the rates of pathological fractures and MSCC [41-42]. Zoledronic acid demonstrated the broadest clinical activity [42]. In a randomized trial of 1130 breast cancer patients, it was superior to pamidronate [43]. Zoledronic acid can cause well-manageable flu-like symptoms. Renal monitoring is recommended, with dose reductions for patients with renal dysfunction. Longterm use of bisphosphonates is associated with a risk of osteonecrosis of the jaw [44]. Other agents such as the RANKligand inhibitor denosumab may also reduce the risk of skeletal-related events such as pathological fractures and MSCC [45].

\section{Conclusions}

For uncomplicated painful bone metastases, single-fraction radiotherapy with $1 \times 8$ Gy may be considered the standard regimen. If re-calcification of the osteolytic bone is a major goal of treatment, longer-course radiotherapy with $10 \times 3$ Gy should be used. In case of an (impending) fracture, mechanical stabilization should be performed, followed by $10 \times 3$ Gy of radiotherapy. For MSCC, $10 \times 3 \mathrm{~Gy}$ is superior to $1 \times 8 \mathrm{~Gy}$ and $5 \times 4 \mathrm{~Gy}$. Because both re-calcification of the osteolytic bone and in-field recurrences of MSCC generally occur only several months following radiotherapy, $10 \times 3$ Gy is preferable in patients with a relatively favorable survival prognosis.

\section{Conflict of Interest}

Amgen: advisory board, honoraria for presentations. Novartis Oncology: research grant, honoraria for presentations.

\section{References}

1 Coleman RE: Clinical features of metastatic bone disease and risk of skeletal morbidity. Clin Cancer Res 2006;12(suppl):6243s-6249s.

$\checkmark 2$ Coleman RE, Rubens R: The clinical course of bone metastases in breast cancer. Br $\mathrm{J}$ Cancer 1987;77:336-340.
3 Bone Pain Trial Working Party: 8 Gy single fraction radiotherapy for the treatment of metastatic skeletal pain (randomised comparison with a multifraction schedule over 12 months of patient follow-up). Radiother Oncol 1999;52:111-121.
4 Foro Arnalot P, Fontanals AV, Galcerán JC, Lynd F, Latiesas XS, de Dios NR, Castillejo AR, Bassols ML, Galán JL, Conejo IM, López MA: Randomized clinical trial with two palliative radiotherapy regimens in painful bone metastases: 30 Gy in 10 fractions compared with 8 Gy in single fraction. Radiother Oncol 2008;89:150-155. 
5 Gaze MN, Kelly CG, Kerr GR, Cull A, Cowie VJ, Gregor A, Howard GCW, Rodger A: Pain relief and quality of life following radiotherapy for bone metastases: a randomised trial of two fractionation schedules. Radiother Oncol 1997:45:106-116.

6 Hartsell WF, Scott CB, Bruner DW, Scarantino CW, Ivker RA, Roach M 3rd, Suh JH, Demas WF, Movsas B, Petersen IA, Konski AA, Cleeland CS, Janjan NA, DeSilvio M: Randomized trial of short- versus long-course radiotherapy for palliation of painful bone metastases. J Natl Cancer Inst 2005;97:798-804.

7 Koswig S, Budach V: Remineralization and pain relief in bone metastases after different radiotherapy fractions ( 10 times 3 Gy vs. 1 time 8 Gy). A prospective study. Strahlenther Onkol 1999;175:500508

8 Nielsen OS, Bentzen SM, Sandberg E, Gadeberg CC, Timothy AR: Randomized trial of single dose versus fractionated palliative radiotherapy of bone metastases. Radiother Oncol 1998;47:233-240.

9 Niewald M, Tkocz HJ, Abel U, Scheib T, Walter K, Nieder C, Schnabel K, Berberich W, Kubale R, Fuchs M: Rapid course radiation therapy vs. more standard treatment: a randomized trial for bone metastases. Int J Radiat Oncol Biol Phys 1996;36:1085-1089.

10 Rasmusson B, Vejborg I, Jensen AB, Andersson M, Banning AM, Hoffmann T, Pfeiffer P, Nielsen HK, Sjøgren P: Irradiation of bone metastases in breast cancer patients: a randomized study with 1 year follow-up. Radiother Oncol 1995;34:179-184.

11 Roos DE, Turner SL, O'Brien PC, Smith JG, Spry NA, Burmeister BH, Hoskin PJ, Ball DL; TransTasman Radiation Oncology Group, TROG 96.05: Randomized trial of 8 Gy in 1 versus 20 Gy in 5 fractions of radiotherapy for neuropathic pain due to bone metastases (Trans-Tasman Radiation Oncology Group, TROG 96.05). Radiother Oncol 2005;75:54-63.

12 Steenland E, Leer JW, van Houwelingen H, Post WJ, van den Hout WB, Kievit J, de Haes $\mathrm{H}$ Martijn H, Oei B, Vonk E, van der Steen-Banasik E, Wiggenraad RG, Hoogenhout J, WárlámRodenhuis C, van Tienhoven G, Wanders R, Pomp J, van Reijn M, van Mierlo I, Rutten E: The effect of a single fraction compared to multiple fractions on painful bone metastases: a global analysis of the Dutch Bone Metastasis Study. Radiother Oncol 1999;52:101-109.

13 Tong D, Gillick L, Hendrickson FR: The palliation of symptomatic osseous metastases. Final results of the study by the Radiation Therapy Oncology Group. Cancer 1982;50:893-899.

14 Souchon R, Wenz F, Sedlmayer F, Budach W, Dunst J, Feyer P, Haase W, Harms W, SautterBihl ML, Sauer R: German Society of Radiation Oncology (DEGRO): DEGRO practice guidelines for palliative radiotherapy of metastatic breast cancer: bone metastases and metastatic spinal cord compression (MSCC). Strahlenther Onkol 2009;185:417-424.

15 Okawa T, Kita M, Goto M, Nishijima H, Miyaj $\mathrm{N}$ : Randomized prospective clinical study of small, large and twice-a-day fraction radiotherapy for painful bone metastases. Radiother Oncol 1988:13:99-104.

16 Price P, Hoskin PJ, Easton D, Austin D, Palmer SG, Yarnold JR: Prospective randomised trial of single and multifraction radiotherapy schedules in the treatment of painful bony metastases. Radiother Oncol 1986;6:247-255.

17 Cole DJ: A randomized trial of a single treatment versus conventional fractionation in the palliative radiotherapy of painful bone metastases. Clin Oncol (R Coll Radiol) 1989;1:59-62.
18 Chow E, Wu JS, Hoskin P, Coia LR, Bentzen SM, Blitzer PH: International consensus on palliative radiotherapy endpoints for future clinical trials in bone metastases. Radiother Oncol 2002;64:275280.

19 Wu JS, Wong R, Johnston M, Bezjak A, Whelan T: Cancer Care Ontario Practice Guidelines Initiative Supportive Care Group: Meta-analysis of dosefractionation radiotherapy trials for the palliation of painful bone metastases. Int J Radiat Oncol Biol Phys 2003;55:594-605.

20 Sze WM, Shelley MD, Held I, Wilt TJ, Mason MD: Palliation of metastatic bone pain (single fraction versus multifraction radiotherapy - a systematic review of randomised trials). Clin Oncol 2003:15:345-352.

21 Chow E, Harris K, Fan G, Tsao MN, Sze WM: Palliative radiotherapy trials for bone metastases: a systematic review. J Clin Oncol 2007;25:1423-1436.

22 Jeremic B, Shibamoto Y, Igrutinovic I: Single 4 Gy re-irradiation for painful bone metastases following single fraction radiotherapy. Radiother Oncol 1999;52:123-127.

23 Mithal N, Needham P, Hoskin, P: Retreatment with radiotherapy for painful bone metastases. Int J Radiat Oncol Biol Phys 1994;29:1011-1014.

24 Chow E, Ling A, Davis L, Panzarella T, Danjoux C: Pain flare following external beam radiotherapy and meaningful change in pain scores in the treatment of bone metastases. Radiother Oncol 2005;75:64-69.

25 Chow E, Loblaw A, Harris K, Doyle M, Goh P, Chiu H, Panzarella T, Tsao M, Barnes EA, Sinclair E, Farhadian M, Danjoux C: Dexamethasone for the prophylaxis of radiation-induced pain flare after palliative radiotherapy for bone metastases a pilot study. Support Care Cancer 2008;15:643-647.

26 Loblaw DA, Wu JS, Kirkbride P, Panzarella T, Smith K, Aslanidis J, Warde P: Pain flare in patients with bone metastases after palliative radiotherapy - a nested randomized control trial. Support Care Cancer 2007:15:451-455.

27 Van der Linden YM, Dijkstra SP, Vonk EJ, Marijnen CA, Leer JW; Dutch Bone Metastasis Study Group: Prediction of survival in patients with metastases in the spinal column. Results based on a randomized trial of radiotherapy. Cancer 2005;103:320-328.

28 Maranzano E, Latini P, Checcaglini F, Perrucci E, Aristei C, Panizza BM, Ricci S: Radiation therapy of spinal cord compression caused by breast cancer: report of a prospective trial. Int J Radiat Oncol Biol Phys 1992;24:301-306.

29 Rades D, Stalpers LJ, Veninga T, Schulte R, Hoskin PJ, Obralic N, Bajrovic A, Rudat V, Schwarz R, Hulshof MC, Poortmans P, Schild SE: Evaluation of five radiation schedules and prognostic factors for metastatic spinal cord compression. J Clin Oncol 2005;23:3366-3375.

30 Rades D, Veninga T, Stalpers LJA, Schulte R, Hoskin PJ, Poortmans P, Schild SE, Rudat V. Prognostic factors predicting functional outcome, recurrence-free survival, and overall survival after radiotherapy of metastatic spinal cord compression in breast cancer patients. Int J Radiat Oncol Biol Phys 2006;64:182-188.

31 Rades D, Fehlauer F, Schulte R, Veninga T, Stalpers LJ, Basic H, Bajrovic A, Hoskin PJ, Tribius S, Wildfang I, Rudat V, Engenhart-Cabilic R, Karstens JH, Alberti W, Dunst J, Schild SE: Prognostic factors for local control and survival after radiotherapy of metastatic spinal cord compression. J Clin Oncol 2006;24:3388-3393.
32 Rades D, Lange M, Veninga T, Stalpers LJ, Bajrovic A, Adamietz IA, Rudat V, Schild SE: Final results of a study comparing short-course and long-course radiotherapy (RT) for local control of metastatic spinal cord compression (MSCC). J Clin Oncol 2009;27(suppl):abstr 9522.

33 Rades D, Dunst J, Schild SE: The first score predicting overall survival in patients with metastatic spinal cord compression. Cancer 2007;112:157-161.

34 Patchell RA, Tibbs PA, Regine WF, Payne R, Saris S, Kryscio RJ, Mohiuddin M, Young B: Direct decompressive surgical resection in the treatment of spinal cord compression caused by metastatic cancer: a randomised trial. Lancet 2005;366:643-648.

35 Robinson RG, Preston DF, Baxter KG, Dusing RW, Spicer JA: Clinical experience with strontium- 89 in prostatic and breast cancer patients. Semin Oncol 1993;20:44-48.

36 Serafini AN, Houston SJ, Resche I, Quick DP, Grund FM, Ell PJ, Bertrand A, Ahmann FR, Orihuela E, Reid RH, Lerski RA, Collier BD, McKillop JH, Purnell GL, Pecking AP, Thomas FD, Harrison KA: Palliation of pain associated with metastatic bone cancer using samarium-153 lexidronam: A double-blind placebo-controlled trial. J Clin Oncol 1998;16:1574-1581.

37 Kraeber-Bodéré F: Treatment of bone metastases of prostate cancer with strontium- 89 chloride: efficacy in relation to the degree of bone involvement. Eur J Nucl Med 2000;27:1487-1493.

38 Hoskin PJ, Ford HT, Harmer CI: Hemibody ir radiation (HBI) for metastatic bone pain in two histological distinct groups of patients. Clin Oncol 1989;1:67-69.

39 Salazar OM, Sandhu T, da Motta NW, Escutia MA, Lanzós-Gonzales E, Mouelle-Sone A, Moscol A, Zaharia M, Zaman S: Fractionated half-body irradiation (HBI) for the rapid palliation of widespread, symptomatic, metastatic bone disease: a randomized phase III trial of the International Atomic Energy Agency (IAEA). Int J Radiat Oncol Biol Phys 2001;50:765-775.

40 Salazar OM, Rubin P, Hendrickson FR, Komaki R, Poulter C, Newall J, Asbell SO, Mohiuddin M, Van Ess J: Single-dose half-body irradiation for palliation of multiple bone metastases from solid tumors. Final Radiation Therapy Oncology Group report. Cancer 1986;58:29-36.

41 Berenson JR, Hillner BE, Kyle RA, Anderson K Lipton A, Yee GC, Biermann JS; American Society of Clinical Oncology Bisphosphonates Expert Panel: American Society of Clinical Oncology clinical practice guidelines: the role of bisphosphonates in multiple myeloma. J Clin Oncol 2002;20:3719_ 3736.

42 Santini D, Fratto ME, Vincenzi B, Galluzzo S, Tonini G: Zoledronic acid in the management of metastatic bone disease. Expert Opin Biol Ther 2006;6:1333-1348.

43 Rosen LS, Gordon DH, Dugan W Jr, Major P, Eisenberg PD, Provencher L, Kaminski M, Simeone J, Seaman J, Chen BL, Coleman RE: Zoledronic acid is superior to pamidronate for the treatment of bone metastases in breast carcinoma patients with at least one osteolytic lesion. Cancer 2004;100:36-43.

44 Ruggiero SL, Mehrotra B, Rosenberg TJ, Engroff SL: Osteonecrosis of the jaws associated with the use of bisphosphonates: A review of 63 cases. J Oral Maxillofac Surg 2004;62:527-534.

45 Body JJ, Lipton A, Gralow J, Steger GG, Gao G, Yeh H, Fizazi K: Effects of denosumab in patients with bone metastases, with and without previous bisphosphonate exposure. J Bone Miner Res 2010;25:440-446. 